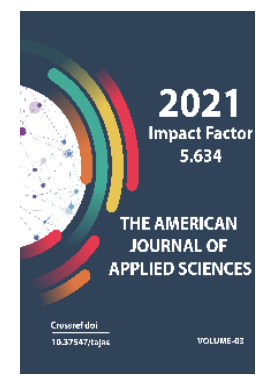

Journal Website: http://theamericanjour nals.com/index.php/taj as

Copyright: Original content from this work may be used under the terms of the creative commons attributes 4.0 licence.

\section{Increasing Agricultural Productivity Of Potatoes By Influencing Crop Elements}

\author{
Abdulla Nurmatovich Khayitov \\ Teacher, Department Of “Transport Systems” Urgench State University, Uzbekistan \\ Alisher Yuldoshevich Atakhanov \\ Teacher, Department Of “Transport Systems” Urgench State University, Uzbekistan \\ Islom Saidovich Atakhanov \\ Teacher, Department Of “Transport Systems” Urgench State University, Uzbekistan \\ Bakhodir Sharifbaevich Radjapov \\ Teacher, Department Of “Transport Systems” Urgench State University, Uzbekistan \\ Sarvar Ibragimovich Rakhimov \\ Teacher, Department Of “Transport Systems” Urgench State University, Uzbekistan
}

\title{
ABSTRACT
}

The main and pre-planting types of soil for planting potatoes are focused on fertilizing potatoes. The main tillage in irrigated agriculture of Uzbekistan includes the following. Crops planted before the fields are used to collect plant residues as well as basic tillage and operational leveling of the fields.

\section{KEYWORDS}

Potato, soil, soil-climate, agricultural crops, potato cultivation technologies, operation, plug, chisel, cultivator, cotton, furrow, yield.

\section{INTRODUCTION}

Requirements for tillage. Irrigation of potatoes on the basis of modern technology of cultivation implies the flatness of the field, regular increase of fertility and improvement of water-physical properties of the soil, as well as the leveling of the soil surface. Conditions are created for high quality and efficient operation of machines in planting, care and harvesting of potatoes by good tillage and capital leveling of the main and pre-planting soil.
Potatoes require quality tillage. It is strongly affected by the compaction of the soil and the increase in moisture in its composition. Potatoes need deep loosened soils that absorb air, water and temperature faster than other crops. The seed tuber planted in the soil, the white root formed from it, and the new nodules formed from it absorb large amounts of oxygen. Due to proper tillage of the soil, it is possible to achieve a normal gas exchange. 


\section{THE MAIN FINDINGS AND RESULTS}

Tillage should ensure that the soil is not compacted into a fine-grained structure, porous, plowed layer before planting potatoes, and that potato roots penetrate freely from the plowing layer and into the layer below it.

Under the resistance of the soil to mechanical stress, small and deformed nodules are formed. This is especially common in loamy and loamy soils with high viscosity. When such soils are compacted, the potato root does not grow towards the deeper layer of the soil, but remains on the surface layer $(0-15 \mathrm{~cm})$. The activity of the microflora slows down due to insufficient absorption of air into these soils. As a result of the porosity of the porous particles in the compacted soils and their high water content, it cannot be absorbed.

Potato yield is directly related to soil compaction and water permeability. According to F. Wirsing (1981), in the German climate, the density of soil is $1.1 \mathrm{~g} / \mathrm{cm}^{3}$, its water permeability is $0.72 \mathrm{~mm} / \mathrm{min}$, and the yield of potatoes is 282 ts / ha, with a density of $1.2 \mathrm{~g} / \mathrm{cm}^{3}$. at 0.22 and 279, $1.3 \mathrm{~g} / \mathrm{cm}^{3}$, respectively -0.08 and 211 and $1.4-0.01 \mathrm{~mm} /$ min and 170 ts / ha, respectively. According to B.A. Pisarev (1971) in low-soil zones the yield of potatoes in heavy soils with a density of 1.1 $\mathrm{g} / \mathrm{cm}^{3}$ was 321 ts / ha, and in areas with a density of $1.4 \mathrm{~g} / \mathrm{cm}^{3}-190 \mathrm{ts} / \mathrm{ha}$. Seeds sown in soil with a density of $1.6 \mathrm{~g} / \mathrm{cm}^{3}$ rotted without forming seedlings. The mechanical composition has little effect on potato yield compared to the compaction of light sandy and loamy soils, the compaction of topsoil and loamy soils. Potato yield in grassy sandy soils with a density of 1.4-1.5 t/ $\mathrm{cm}^{3}$ was $240-245 \mathrm{ts} /$ ha, $1.6 \mathrm{~g} / \mathrm{cm}^{3}-233$ ts / ha and 133 ts / ha at 1.7 $\mathrm{g} / \mathrm{cm}^{3}$.

When getting a high yield from potatoes, it is necessary to avoid excessive compaction of the soil. To do this, when performing field work, it is necessary to follow the parameters of the pressure of the moving systems of the mechanisms on the soil and the value of soil compaction. (Table 1).

Table 1 Density value of dry soil and limits of maximum allowable pressure on the soil (ground) during its cultivation

\begin{tabular}{|c|c|c|c|c|c|c|}
\hline \multirow[t]{2}{*}{ Soil types } & \multicolumn{3}{|c|}{ Particle size in soil, mm } & \multirow{2}{*}{$\begin{array}{c}\text { The density } \\
\text { value limit of } \\
\text { dry soil is } \mathrm{g} / \\
\mathrm{cm}^{3}\end{array}$} & \multicolumn{2}{|c|}{$\begin{array}{l}\text { Maximum pressure on the } \\
\text { ground. } \mathrm{kPa}\end{array}$} \\
\hline & $\begin{array}{c}0,02 \\
\text { (mud) }\end{array}$ & $\begin{array}{c}0.002 \ldots . . \\
0.063 \\
\text { (dusty } \\
\text { soil) }\end{array}$ & $\begin{array}{c}0,063 \ldots . \\
2,000 \\
\text { (sand) }\end{array}$ & & $\begin{array}{c}\text { In the spring } \\
\text { (field } \\
\text { moisture } \\
\text { capacity } \\
80 \%)\end{array}$ & $\begin{array}{c}\text { In summer } \\
\text { and autumn } \\
\text { (field } \\
\text { moisture } \\
\text { capacity } \\
70 \% \text { ) }\end{array}$ \\
\hline Sand & 3 & 17 & 80 & 1,54 & & \\
\hline
\end{tabular}




\begin{tabular}{|c|c|c|c|c|c|c|}
\hline Bound sand & 5 & 20 & 75 & 1,52 & \multirow[t]{2}{*}{50} & \multirow[t]{2}{*}{80} \\
\hline Sandland & 10 & 25 & 65 & 1,50 & & \\
\hline Light healthy soil & 15 & 30 & 55 & 1,48 & \multirow{3}{*}{80} & \multirow{3}{*}{150} \\
\hline Moderately healthy & 20 & 40 & 40 & 1,45 & & \\
\hline Heavy healthy soil & 25 & 55 & 20 & 1,45 & & \\
\hline Light clay soil & 40 & 35 & 25 & 1,35 & \multirow[t]{2}{*}{120} & \multirow[t]{2}{*}{200} \\
\hline Average clay soil & 50 & 30 & 20 & 1,30 & & \\
\hline
\end{tabular}

A well-drained soil can be obtained when it is fully cultivated. However, the treated soil cannot keep its condition for long. The soil decreases in size under the influence of its own weight and precipitation. To maintain a favorable condition of the soil for potatoes, it is necessary to carry out this or that tillage.

Due to the growing demand for the quality of potato crops, it is necessary to prevent the formation of lumps, especially in heavy soils. In heavy soils, the formation of lumps in the soil is caused by factors such as the wheels of tractors, machines and mechanisms, the pressure of the working bodies, rain, snow, wind and the pressure of the soil itself. When the crop is harvested, lumps the size (volume) of which is equal to the size of the tuber fall into the vortex, and additional work is done to separate it. The soil should have the same dimensional structure when prepared for potatoes. It is advisable that the size of the particles formed by soil compaction does not exceed $12 \mathrm{~mm}$.

When the soil is tilled, it must ensure that the remains of past and intermediate crops, the applied organic and mineral fertilizers are buried at the same depth in the tillage layer of the soil.
Proper tillage, along with improving its physical and chemical properties, solves the following problems:

- Mechanical weeding and clearing the field;

- Elimination of pests and pathogens;

- Ensuring the absorption and storage of autumn-winter precipitation in the soil in areas with insufficient moisture, as well as the removal of high moisture content and the retention of moisture in the soil;

- To obtain the edges at a convenient and uniform height to protect the growth and development of the potato plant and the tubers from damage during harvesting by mechanical means;

- Conditioning and storage of soil for quality technological processes.

Preparation of land for planting potatoes consists of basic and pre-sowing measures, which include:

- Removal of plant debris or crushing of corn stalks;

- Cultivation of intermediate crops;

- Application of organic and mineral fertilizers;

- Weed control;

- Plowing; 
- Take the edges before planting (autumn or spring);

- Pre-sowing cultivation and harrowing.

In the context of irrigated agriculture in Uzbekistan, the current leveling of the land is also part of the land preparation complex for potatoes.
A superficial look at the process of preparing the soil for planting gives a negative result. They should be carried out depending on the climatic conditions of the soil in which the potato is grown, as well as weather conditions and the timing of its planting. The mechanical composition is different from that of light soils, medium and heavy soils (Table 2 ).

\section{Cultivation of potato soils in different ways}

\begin{tabular}{|c|c|c|c|c|c|c|c|c|c|}
\hline \multirow{2}{*}{ Processing method } & \multicolumn{3}{|c|}{ Light soil } & \multicolumn{3}{|c|}{ Average soil } & \multicolumn{3}{|c|}{ Soil prone to cracking } \\
\hline & 1 & 2 & 3 & 1 & 2 & 3 & 1 & 2 & 3 \\
\hline Autumn processing: Surface & $\mathrm{x}$ & & & & & & & & \\
\hline Deep & & & & & $x$ & $x$ & $x$ & $x$ & \\
\hline Getting a bow in the fall & & & & & & & $x$ & & \\
\hline Plowing in the spring & $\mathrm{x}$ & $x$ & $x$ & $\mathrm{x}$ & & & & & $\mathrm{x}$ \\
\hline Getting rid of before planting in the spring & & $\mathrm{x}$ & & & & & & & \\
\hline Cultivation and harrowing & & & $\mathrm{x}$ & & & $\mathrm{x}$ & & $\mathrm{x}$ & \\
\hline Cultivation twice & & & & & & $x$ & & & \\
\hline Planting & $x$ & $\mathrm{x}$ & $x$ & $\mathrm{x}$ & $x$ & $\mathrm{x}$ & $x$ & $x$ & $x$ \\
\hline
\end{tabular}

Note: 1 is good for this condition; 2- possible; 3 - bad, methods

It is highly effective if the methods of land preparation for potatoes are carried out in a certain order and in an environmentally and economically interconnected way with a very low intensity and a reduction in the number of works to be performed.

Basic tillage. In the hot arid climate of Uzbekistan and in the conditions of 
agriculture through artificial irrigation, the main cultivation of potato land has its own characteristics. Irrigated lands quickly lose their soft structure under the influence of tillage and other mechanisms, as well as conducted irrigation. Destruction of the structure and its transformation into dusty soil reaches a layer of $15-20 \mathrm{~cm}$. It also has the property of forming a closed layer after the top $20-25 \mathrm{~cm}$ layer of soil. Therefore, it is advisable to cultivate the soil to a depth of 27$30 \mathrm{~cm}$ to improve the granularity of the soil and soften the berg layer.

The main driving in the fall is called plowing. Deep plowing of the land in autumn reduces weed infestation, prevents pests and diseases, improves water and air order in the soil, and accumulates more nutrients; increases the effectiveness of the given mineral fertilizers, ensuring that the plant roots grow into the deeper layers of the soil and that it is evenly distributed in the soil layer. It is not always possible to plow meadow-swamp soils with low fertility, gravel layer and topsoil layer at a depth of $2730 \mathrm{~cm}$. In such cases, the plowing depth of the soil is increased by $2-3 \mathrm{~cm}$ per year, and it must be carried out with the application of organic fertilizers.

The best time for plowing in Uzbekistan is late October-November. Many heavy soils containing clay should be plowed in early autumn. Delayed plowing increases the moisture content of the soil, which adversely affects its quality and increases fuel costs. In addition, if more time elapses between the harvest of the evening crop and the plowing, in such cases the land should be plowed after the surface has been softened.

In Uzbekistan, crops are irrigated by tillage, so the main tillage system begins with the leveling of temporary irrigation canals, clearing the field of plant debris and the application of organic fertilizers.

Temporary irrigation stations will be leveled using KZU-0.3 and MK-12 implements mounted on plowing tractors, and collection and removal of plant debris will be carried out with KPS-4-03 devices.

If the soil is loosened early from the crop and overgrown with weeds, it is plowed shallow before plowing. Late-crop, weed-free soils are plowed without shallow plowing. Shallow loosening of the soil is carried out using disc hydrophilic LDG modification, PPL-1-10-25 plugs or by removing the inverter of ordinary plugs. In heavy soils with mechanical composition, its softening is carried out by means of heavy-duty disc harrows BDNT-2,2 and BD-10.

Soils covered with annual weeds are loosened to a depth of 6-7 cm, and those contaminated with perennial weeds to a depth of $10-14 \mathrm{~cm}$. In the dry years of autumn, the soil is irrigated after shallow loosening. Irrigation of the land leads to a certain reduction in weeds. Soils occupied with perennial grasses are discarded by a storm on the neck and cross-section 7-8 days before plowing.

The soil is plowed 2-3 weeks after shallow loosening. Organic and mineral fertilizers are applied before plowing.

The land should be plowed when it is ripe in the fall. When driving in very wet soils, the tractor wheels follow the last trail of the plow, which negatively affects the yield of potatoes. As a result of the formation of the maple layer, the plant absorbs water and nutrients only from the tillage layer. After plowing the land should be qualitatively leveled the 
irregularities that form on its surface. After the field is plowed, the area where the tractor turns is cultivated.

After plowing the land contaminated with perennial weeds, its roots and remains are cleaned with a gun VKS-08.

In the conditions of irrigated agriculture in Uzbekistan, one of the main types of tillage is the leveling of the land with the help of longbase mechanisms. It is performed using longbase mechanisms.

Tillage before planting. The main purpose of tillage before planting potatoes is to loosen the tillage layer of compacted soil in the autumn-winter and early spring periods. It is also important to store the moisture that has accumulated during the winter, clear the field of weeds, and mix the fertilizer into the soil. It is necessary to create conditions for the soil to have a stable fine-grained structure with sufficient porosity and good retention of moisture in the subsoil.

As a result, in the soil layer where the seed is planted, favorable conditions are created for it to sprout and grow well.

Cultivation of potatoes before planting includes the following processes:

- Deep and even loosening of the soil with maximum retention of natural moisture;

- Shredding of lumps;

- Crushing and leveling of soil surface;

- Restoration of subcutaneous capillaries in which the seed tuber is planted due to recompaction of the soil.

The quality of pre-sowing tillage depends on the quality of the main tillage in the fall: correcting the shortcomings in the autumn plowing - reduces the yield of potatoes and tuber quality, while requiring excessive costs.

The soil is sensitive to spring pressures. Therefore, during the pre-planting tillage period, its moisture content should be less than $75 \% \mathrm{NV}$, and during the transfer period, tractors and other machinery should be less (crushed) in the field. In spring, the maximum pressure on it, depending on the type of soil: sandy and loamy soils - 50, light, medium and heavy soils - 80 , light and medium clay soils $120 \mathrm{kPa}$. The following measures are recommended to reduce the pressure on the ground by the wheels: the internal pressure of the tractor tires should be reduced as much as possible; the wheels of the same size should be fastened with a connecting pad as much as possible.

Fertilization of potatoes plants. In all cases, the current leveling should be included in the process of tillage before planting for late potatoes.

Potatoes are very sensitive to fertilizers. One of the main factors in obtaining high yields, quality and formation of tasty buns is the fertilization of potatoes.

Nitrogen, phosphorus, potassium, calcium, magnesium, iron, sulfur, barium, manganese and other nutrients are necessary for good growth of potatoes. Each element plays a specific role in plant life, and a lack of any of the mineral nutrients negatively affects plant growth.

The influence of the main elements in mineral nutrients on the growth, development and yield of potatoes varies depending on soil moisture, supply of other nutrients and other factors. In terms of extracting the main elements of mineral nutrients from the soil, 
potatoes are far superior to cereals, close to sugar beets and corn.

The amount of minerals in potato tubers and stems is not the same. Their amount varies depending on growing conditions, variety, and application of fertilizers. Information on the amount of macro-and micronutrients in potatoes is given in the table below.

The amount of nutrients in potato tubers and stalks

\begin{tabular}{|c|c|c|}
\hline \multicolumn{3}{|c|}{ Bunches } \\
\hline \multicolumn{3}{|c|}{ Macronutrients $(\mathrm{kg} / \mathrm{ts})$} \\
\hline $\mathrm{N}$ & $0,3 \ldots 0,4$ & $0,3 \ldots ., 5$ \\
\hline $\mathrm{P} 2 \mathrm{O} 5$ & $0,12 \ldots 0,16$ & $0,1 \ldots .0,2$ \\
\hline $\mathrm{K} 2 \mathrm{O}$ & $0,55 \ldots 0,65$ & $0,5 \ldots ., 25$ \\
\hline $\mathrm{MgO}$ & $0,06 \ldots 0,10$ & $0,15 \ldots ., 25$ \\
\hline $\mathrm{CaO}$ & $0,01 \ldots 0,005$ & - \\
\hline $\mathrm{S}$ & $0,001 \ldots 0,03$ & $0,03 \ldots .0,05$ \\
\hline \multicolumn{3}{|c|}{ Trace elements $(\mathrm{mg} / \mathrm{kg})$} \\
\hline $\mathrm{Fe}$ & $1,76 \ldots 2,64$ & $5,00 \ldots 7,50$ \\
\hline $\mathrm{Zn}$ & $0,22 \ldots 0,88$ & $2,50 \ldots 7,50$ \\
\hline $\mathrm{Cu}$ & $0,44 \ldots 0,88$ & $1,25 \ldots 2,50$ \\
\hline $\mathrm{B}$ & $0,22 \ldots 0,44$ & $0,25 \ldots 0,75$ \\
\hline $\mathrm{Mo}$ & $0,22 \ldots 0,66$ & $0,10 \ldots 0,15$ \\
\hline $\mathrm{yn}$ & $0,01 \ldots 0,02$ & $0,02 \ldots 0,05$ \\
\hline
\end{tabular}

In terms of the amount of nutrients, their extraction from the soil can be determined by multiplying the amount of yield.

Potatoes make fuller and more efficient use of nutrients when favorable conditions for plant growth are created, i.e. when water, heat, light are provided at the required level and fertilizer standards are optimal. According to the data obtained from different potato growing areas, each ton of potatoes grown under optimal conditions receives $4.0-6.0 \mathrm{~kg}$ of nitrogen, $1.5-2.5 \mathrm{~kg}$ of phosphorus and 6.0$10.0 \mathrm{~kg}$ of potassium from the soil. Nitrogen, phosphorus and potassium are absorbed more by potato plants during the period of pruning and flowering, that is, during the most intensive development of the stems and stems. During this period, $75 \%$ of the required amount of nitrogen, $50 \%$ of phosphorus and $60 \%$ of potassium are absorbed.
The absorption of mineral nutrients by potatoes in the soil decreases after flowering; the nutrients accumulated in the stem are assimilated. At the time of harvest, the total amount of nitrogen in the plant in the tubers is $78-80 \%$, phosphorus - $90 \%$, potassium - $96 \%$.

To get high yields and quality ends, the plant must receive the right amount of fertilizer at the right time. Good results can be achieved if fertilizers are applied, taking into account the amount of nutrients in the field and the demand of plants for fertilizers.

Local (manure, compost, siderates, etc.) and various mineral fertilizers are a source of nutrients needed for potatoes.

Prolonged application of local fertilizers improves soil composition, water, air and heat conditions, light soils retain nutrients and water in the topsoil, and heavy soils - water and air permeability. This is especially 
important for potatoes, because the crop of tubers is formed in the drive layer. At the same time, there are white blood cells (stolons), the cells of which are several times larger than the stem cells. The large cellular structure of the white veins allows for partial displacement of the soil particles. Therefore, well-circulated, soft soil has a positive effect on plant growth and yield.

As a result of chronic application of local fertilizers, phosphorus-acid compounds and potassium accumulate in the soil, gradually decreasing hydrolytic acid, the amount of humus increases slightly.

Nitrogen fertilizers play an important role in the formation of high yields of potatoes. The share of nitrogen in this process is not less than $20 \%$. Nitrogen deficiency reduces potato yields due to slow and low germination of tubers and more timely death of stems. When more than the norm of nitrogen is given, the stem becomes rough, the growth and maturation of the stem slows down and the yield decreases. However, in some cases, if more nitrogen is applied in early maturing varieties or if the growing season is long, it will increase the yield and enlarge the stems. On the other hand, the abundance of nitrogen reduces the taste of cloves, water in them increases and darkens, storage deteriorates, the incidence of disease increases, leading to the accumulation of nitrates.

\section{CONCLUSION}

Lightly soluble phosphorus compounds in mineral fertilizers, when applied to irrigated soils, turn into slowly soluble compounds, especially in hydromorphic meadow and meadow-swamp soils. The phosphates in the fertilizer do not move in the soil and they are in the place where the fertilizer is applied.
Phosphorus fertilizers should be applied closer to the place where the roots of the plants are located, taking into account the application to deep layers of soil or between rows and furrows. Due to the very slow solubility of phosphorus compounds, it is advisable to apply the bulk of phosphorus fertilizers before plowing in the fall, and only part of it should be given during the growing season of the plant.

The phosphorus utilization rate of the plant is small: this figure is usually $15-20 \%$ per year of fertilizer application; this figure is significantly higher when mineral phosphorus fertilizers are applied in combination with organic fertilizers, especially in the form of granules between furrows and rows.

When potassium fertilizers are applied to the soil, most of the potassium (80\%) immediately enters the soil absorption complex, and then the plant uses it permanently in the form of exchangeable potassium. Therefore, the bulk of potassium fertilizers are given at plowing or pre-sowing tillage and only a portion at the first feeding.

\section{REFERENCES}

1. Zuev V.I., Buriev X.Ch. Kodirxujaev O.K. Azimov B.B. (2016) Potato. - Tashkent: "Creative House of Publishing and Printing named after Gofur Gulom". (Зуев В.И., Буриев Х.Ч. Кодирхужаев О.К. Азимов Б.Б. Картошкачилик Т., «Гофур Гулом номли наширёт-матбаа ижодий уйи », 2016.)

2. Buriev X.Ch, Zuev V.I., Kodirxujaev O.K., Muxamedov M.M. (2002) "Progressive technologies of growing vegetables in the open field". - Tashkent. "National 
Encyclopedia of Uzbekistan". (Буриев Х.Ч, Зуев В.И., Кодирхужаев О.К., Мухамедов М.М. «Очик жойда сабзавот экинлари етиштиришнинг прогрессив технологиялари» Т., “Узбекистон миллий энциклопедияси" 2002.)

3. Abdukarimov D.T., Astanakulov T.S. (2004) Two-yield crop and potato cultivation from true seeds. On Sat. Art. "Potato growing in Uzbekistan". Tashkent: Ministry of Agriculture and Water Resources. (Абдукаримов А.Т., Астанакулов Т.C. Двухурожайная культура и вўрахивание картофеля из истиннўх семян. В сб. ст. “Картофелеводство Узбекистана". Ташкент. МСBX, 2004.)

4. Balashev N.N. (1953) Summer planting of potatoes with freshly harvested tubers. In the book. "Potato culture in Uzbekistan". - Tashkent: State Publishing House. (Балашев Н.Н. Летние посадки картофеля свежеубраннўми клубнями. В кн. “Культура картофеля в Узбекистане”. Ташкент. Госиздат, 1953.)

5. Kolchina L.M. (2014) Technologies and equipment for potato production. Moscow: Federal State Budgetary Scientific Institution "Rosinformagrotech". (Колчина Л.М. Технологии и оборудование для производства картофеля. М.: ФГБНУ “Росинформагротех", 2014.)

6. Tubolev S.S. and others. (2010) Machine technologies for potato production. Moscow: Agrospas. (Туболев С.С. и др. Машинные технологии для производства картофеля.- М.: Агроспас, 2010.)

7. Standard technological maps for the care and cultivation of agricultural crops for 2016-2020. Part II. - Tashkent: - 2016.
(Қишлоқ хўжалиги экинларини парваришлаш ва махсулот етиштириш бўйича намунавий технологик карталар 2016-2020 йиллар учун. II қисм.Тошкент - 2016.)

8. Augambaev M., Ivanov A.Z., Terekhov Yu.I. (1993) Basics of planning a research experiment. -Tashkent: Ukituvchi. - p. 336. (Аугамбаев М., Иванов А.3., Терехов Ю.И. Основы планирования научно-исследовательского

эксперимента. -Ташкент: Ўкитувчи, 1993.- 336 c.)

9. Johnson N., Lyon F. (1981) Statistics and Experiment Planning in Engineering and Science. - Moscow: Publishing house “Mir”. - p. 516. (Джонсон Н., Лион Ф. Статистика и планирование эксперимента в технике и науке. - М.: Издательство «Мир», 1981. - 516 с.)

10. ISS 20915-15. Agricultural machinery tests. Methods for determining conditional tests. - Moscow: Standartinform, 2013. p. 23. (ГОСТ 20915-15. Испытания сельскохозяйственной техники. Методы определения условый испытаний. - Москва: Стандартинформ, 2013. - 23C.)

11. ISS 3090: 2016 "Testing of agricultural machinery. Machines and weapons for threshing crops. Agrotechnical evaluation of test methods »Tashkent, 2016. (O'z Dst 3090:2016 «Қишлоқ хўжалиги техникасини синаш. Чопиқ экинларига ишлов берувчи машина ва қуроллар. Синов усулларини агротехник бахолаш» Тошкент, 2016.)

12. ISS 3193: 2017 "Testing of agricultural machinery. Methods for energy assessment of machines". - Tashkent: 2001 - p. 59. (O'z Tst 3193:2017 «Испытания сельскохозяйственной 
техники. Методы энергетической оценки машин». -Тошкент, 2001 - 59 с.)

13. Standards of consumption of labor and material resources required for the cultivation of agricultural products. Tashkent: Research Institute of Agricultural Economics., 2016. - 80 p. (Қишлоқ хўжалик махсулотлари етиштиришда талаб этиладиган мехнат ва моддий ресурслар сарфи меъёрлари.

- Тошкент: қХИИТИ, 2016. - 80 б.) 